\title{
LOS ESPACIOS URBANOS COMO PAISAJES DE LAS CIUDADES HISTÓRICAS CONTEMPORÁNEAS EN EL PERÚ
}

\author{
URBAN AREAS AS LANDSCAPES OF CONTEMPORARY HISTORICAL \\ CITIES IN PERU
}

\section{La plaza mayor como espacio simbólico de integración social urbana y de paisaje urbano}

The main square as a symbolic space of urban social integration and urban landscape

Arq. Juan De Orellana Rojas ${ }^{1}$

\begin{abstract}
"La casa de una familia sirve a la familia y por ello termina convirtiéndose en autoexégesis del rango y de las apetencias de esa familia dentro del orden social en que vive. Todo hombre -así como la institución en la que se ordena o a la que se identifica o a la que se subordina- se identifica con el edificio que manda construir. De la pluralidad de instituciones de diversa índole surge la ciudad como institución que todo abarca"
\end{abstract}

Leon Battista Alberti

\begin{abstract}
RESUMEN
Desde la aparición de los primeros asentamientos urbanos se inició, de manera intuitiva, la formación y uso de los espacios urbanos. Al principio no hubo racionalización ni reflexión acerca de los mismos y su trascendencia social, sino que eran simples remanentes entre una construcción y otra. En algunos casos, no existía ni siquiera un concepto de calle. El acomodo era espontáneo y aditivo. Cuando estos asentamientos desarrollaron y, paralelamente, la sociedad fue cambiando lentamente hacia una economía de excedentes, hubo necesidad de lugares de encuentro social e intercambio marchante. La separación de las agrupaciones de construcciones dio lugar a los "ancho" de calles, que luego fueron convirtiéndose en espacios más regulares, lo que dio lugar a las plazas. Las plazas son muy antiguas en las ciudades de occidente, pero las plazas, tal como las conocemos hoy, son de la edad moderna y su concepción tiene una clara y fuerte influencia de las grandes culturas americanas prehispánicas. Se terminará con un estudio de casos.
\end{abstract}

\section{Palabras clave}

Plazas urbanas; plazas mayores; plazas de armas; espacios urbanos, paisaje urbano; simbolismo del espacio urbano

\section{ABSTRACT}

Since the emergence of the first urban settlements began, intuitively, the formation and use of urban spaces. At first there was no rationalization or reflection of them and its social importance, but were

\footnotetext{
Arquitecto por la Universidad Ricardo Palma. Maestría en Arquitectura en la Universidad Nacional Federico Villarreal; Maestría en Restauración de Monumentos en Arquitectura y Urbanismo en la Universidad Nacional de Ingeniería; Especialista en Arquitectura Paisajista. Docente principal de la Facultad de Arquitectura en la UNIFÉ. Miembro de ICOMOS, representante peruano ante el Comité Científico Internacional de Paisajes Culturales (ICOMOS IFLA) y del Comité Científico Internacional de Patrimonio Cultural Inmaterial (ICICH).
} 
merely remnants between one building and another. In some cases, there was even a concept of street. The accommodation was spontaneous and additive. When these settlements developed and, in parallel, society slowly changed into a surplus economy, there was need for social meeting places and exchange dealer. The separation of groups of buildings led to the "width" of streets, which then were becoming more regular spaces, which resulted in the squares. The plaza are very old in the cities of the West, but the plazas as we know them today are of the modern age and its design has a clear and strong influence of large pre-Columbian American cultures. It will end with a case study.

\section{Key words}

Urban spaces, plazas, open spaces in town, urban spaces, urban landscape, symbolism of urban space.

\section{UN POCO DE TEORÍA}

Pareciese que en el mundo occidental la plaza, como concepto urbano actual, hubiese existido desde siempre, pero veremos, a lo largo del presente trabajo, que ello se inició en el s. XVI, en la América española, con los Augsburgo.

El sedentarismo que motivó la gran revolución neolítica dependiente de la agricultura y llevó a la concepción de una arquitectura permanente, frente a la efímera del período nomádico o trashumante. La agricultura y sus labores culturales obliga a permanecer en un lugar; la permanencia obliga a la búsqueda de un cobijo permanente que satisfaga las necesidades que se le presentan en la sociedad que la habitará. Podemos inferir que, en una primera etapa las construcciones serían de grupos humanos que pensaríamos como familias extendidas, grupos de familias $y$ hasta clanes unidos por intereses comunes $y$ de defensa. La vida en las cuevas marcó a esa organización social inicial. En algunos casos, bajo el mismo techo vivían varias familias, con un lugar central para el fogón, y un sitio de privilegio para el jefe. En otros casos, era posible que varias casas estuviesen juntas o cercanas pero no se puede decir que conformaran espacios urbanos propiamente dichos. Ello vendrá después.

\section{Composición de espacios}

Si nos basamos en la física clásica, siempre habrá una relación de distanciamiento (por tanto, tiempo) entre dos objetos, cualesquiera sea su tamaño, desde dos electrones, hasta dos galaxias. Pero, ¿Qué es lo que hace que un espacio sea arquitectónico o sea urbano? La respuesta a esta interrogante es algo que no ha sido respondido satisfactoriamente por los teóricos de la arquitectura. Hay muchos libros y ensayos que han acometido esta empresa ${ }^{2}$, sin que los resultados de los mismos lleguen a satisfacer a todos los arquitectos o urbanistas.

Partamos de un primer principio: no hay, no puede haber, arquitectura ni ciudad sin espacio, por cuanto el hombre precisa de espacio para desarrollar sus actividades y es la arquitectura la disciplina que provee al hombre del hábitat adecuado para que este desarrolle sus actividades y darle cobijo. Sin un espacio adecuado para el cobijo confortable para el desarrollo de dichas actividades y de las necesidades existenciales o expectativas, no hay arquitectura, solo escultura o, a lo sumo, construcción.

Hemos dicho que el espacio es una relación de distanciamiento entre dos elementos. Pero eso, en arquitectura, no es suficiente pues si no ¿Bastaría que haya dos piedras separadas para marcar un espacio arquitectónico? La respuesta es negativa. Para que haya arquitectura se requiere que haya una intencionalidad al conformar los espacios. Estas intenciones responden directamente a preguntas de diversa índole. Las obvias son la funcional y la del

\footnotetext{
2 Citemos los, tal vez, más conocidos: El espacio en arquitectura, la evolución de una idea nueva en la teoría e historia de los movimientos modernos de Cornelis Van de Ven; Existencia Espacio y Arquitectura de Christian Norberg-Schultz; Arquitectura forma, espacio y orden, de Francis Ching; Proxemística; sobre el uso antropológico del espacio, de Luis Rodríguez Cobos; La forma arquitectónica, de Ignacio Araujo y muchos otros pero, en realidad, cada arquitecto que teoriza tiene una definición propia.
} 
confort ambiental, que son las físicas mínimas. De estas se desprenden otras que tienen que ver, sea con la interrelación de dichos espacios a través de conectores, sean puertas, ventanas, simples vanos, espacios de conexión, etc., con lo que queda claro que los espacios no servirían en arquitectura si fueran estancos. Igualmente, los espacios deben ser habitables, es decir, tener las dimensiones apropiadas y albergar el volumen de aire requerido para que en él funcionen las actividades programadas. La iluminación y ventilación etc.

Pero, más allá de esto hay requerimientos humanos referidos a la existencia y al espíritu. Estos pueden ser de diversa índole, pero algo que marca notablemente algunos aspectos existenciales del espacio arquitectónico son la proporción, la escala y el ritmo.

La estética en la arquitectura no se juzga solo por su maravilloso juego de volúmenes bajo el sol. No se trata de escultura. No solo se juzga por su superficie y el tratamiento plástico que se haga de ella, bien sea por color, texturas y ornamento. No es decoración. La estética de la arquitectura se juzga, sobre todo por el espacio, aunque pocas veces se teorice directamente sobre ello. Es el espacio el que debe resultar apto para albergar las funciones para las que está diseñado. Pero si bien gran parte de la cualidad estética del espacio está en la satisfacción de las funciones para las que está concebido, no es la única razón por la que se lo puede cualificar con criterios estéticos ${ }^{3}$. Hay, podríamos decir, otras "funciones", existenciales, perceptivas o espirituales. Podríamos llamarle belleza, aunque el término no es del todo correcto. Se trata de la forma, proporción y de la escala.

La proporción es la relación (en realidad matemática, pero para el caso visual o perceptiva) que existe entre las dimensiones de cada elemento que cierra el espacio y entre los elementos mismos. El rectángulo áureo es una forma de proporción de un elemento (plano), el mismo que se relacionará con otros para conformar un espacio habitable, con una forma determinada. Pensemos en la forma más común, el rectángulo. Podemos imaginar nuestra habitación u oficina, pero también podemos referirnos, bajo esa forma, a esos pasillos característicos de las edificaciones de la cultura Wari como Pikillacta, por ejemplo, con una proporción de 1 a 300, por ejemplo es decir, de $2,70 \mathrm{~m}$ por $650,00 \mathrm{~m}$. Es válido como pasillo, mas no como habitáculo ya que su longitudinalidad, perceptivamente, nos tracciona, nos tensa, nos invita a recorrerlo antes que a habitarlo ${ }^{4}$. A ese plano rectangular muy alargado, al momento de darle tres dimensiones, podemos ponerle paredes de $2,50 \mathrm{~m}$ y percibírsele como pasillo. Pero si, como sucede en Pikillacta, le diésemos una altura de 12,00, a las paredes laterales, sería intolerable incluso como pasillo. El espacio, que con $2,50 \mathrm{~m}$ no se le consideraría cualidades estéticas, al tener los $12,00 \mathrm{~m}$ de altura, contrariamente, se le consideraría antiestético, aun cuando existiesen razones de índole funcional para que dicho pasillo tuviese esas proporciones incómodas a la percepción normal. De manera semejante, podemos pensar en un lobby cuadrado de $20,00 \mathrm{~m}$ de lado, para albergar muchos usuarios contemporáneamente. Con una altura de 9 metros, tiene una proporción perceptivamente agradable ("estética"). Pero si se le diese una altura de 2,50 m (suficiente para el movimiento humano y sus funciones normales) resultaría espantosamente "aplastante" en sentido vertical, de la misma forma que el pasillo de 12 m resultaría "aplastante" en sentido horizontal. Esto es respecto a las relaciones numéricas entre las diferentes dimensiones.

Como puede verse no solo se trata de cumplir la función objetiva, que es básico hacerlo. Hay un manejo subjetivo, ciertamente, o culturalmente intersubjetivo, que otorga a los espacios ciertas cualidades estéticas.

Aunque no es rigurosamente correcto, cuando se habla de la forma, se piensa en la forma exterior de la arquitectura, vale decir, en su forma másica, mal llamada volumetría. Mal llamada, porque no es una medida de volumen $\mathrm{y}$, al referirnos a volumen, no solo es el exterior, sino que también tiene volumen

\footnotetext{
3 Roger Scruton: La estética en arquitectura (1985).

4 Christian Norberg-Schultz: Existencia espacio y arquitectura. (1975).
} 
el espacio interior, como que también tiene forma. Pensemos que, al retirarle el techo a una edificación, podríamos hacer un vaciado de algún material (como en el molde de una escultura) y veríamos la forma del espacio (en positivo, si pensamos que el espacio es el negativo $)^{5}$.

La escala se refiere a las dimensiones reales que caracterizan un espacio o una masa. $\mathrm{Si}$ tomamos como ejemplo la Catedral de Lima, podemos hacer una construcción a la quinta o décima parte de su tamaño real, a pesar de representar arquitectura, no lo es, porque no se podría desarrollar en su interior los ritos para los que está hecho. Si fuese cinco veces más grande, si bien se podría desarrollar dichas actividades, la escala excedería lo humano, aún cuando se pudiese argumentar que se trata de escala divina y no humana, pero serán los humanos quienes la usarán. Será efectivo si nuestra idea de Dios es de un ser intimidante, agobiante.

El ritmo, en cuanto a espacios habitables se refiere, es la sucesión de espacios que se interrelacionan y las diferentes sensaciones que generan. Como es el caso de las iglesias paleocristianas $\mathrm{o}$, sin retroceder tanto, la catedral de brasilia, en la que la entrada se produce descendiendo por una rampa flanqueada de santos, penetrando desde la luz total del exterior, a un espacio de techo muy bajo, en penumbra y casi oscuridad (tinieblas) para llegar a la luz refulgente del gran interior donde se encuentra Dios. La secuencia rítmica es muy mística. Miguel Ángel, en la Biblioteca Laurenciana, hizo un trabajo genial de ritmo espacial, creando un espacio agobiante a fin de celebrar una escalera que no es tan monumental como parece. Esa sensación de agobio se produce por la magnífica articulación superficial de los muros que encierran $y$ delimitan el espacio.
De aquí podemos desprender un segundo principio: el espacio necesita límites y, por lo tanto, de limitantes. Si hemos dicho que se trata de una relación de distanciamiento, en primer lugar, hablamos de distancia mensurable y de elementos (limitantes) que estén distanciados. La distancia la podemos medir en micrones o en años luz (tiempo). En arquitectura los limitantes son másicos, tanto explícitos, como implícitos. El punto de contacto entre el espacio y la masa es la superficie, el tercer elemento. Según Araujo ${ }^{6}$, la superficie tiene textura y color, sus dos cualidades. El manejo de esa superficie define ciertas cualidades del espacio, como la iluminación, la percepción de las dimensiones, la reverberación acústica ${ }^{7}$, etc. Toda masa tiene superficie y la percibimos a través de ella, y por eso solemos confundirlas. Al percibir el espacio, percibimos siempre la superficie de la masa que lo delimita y, algunas veces, percibimos la forma de la masa misma.

La forma del espacio también influye en la percepción estética del mismo espacio ${ }^{8}$. El ser humano, psicológicamente, tiende a reducir a algo conocido o reconocible aquello que percibe. Es el origen de las pareidolias. A menudo vemos nubes, manchas en el pavimento, agrupaciones de estrellas, con formas aleatorias y les asignamos la forma de una figura conocida. Asignamos formas $\mathrm{de}$ animales, teteras, $\mathrm{u}$ otros, en este acto pareidólico. Si lo que asociamos a esa forma es algo divino o religioso, como ver la imagen de la Virgen María en la refracción de un vidrio, se le suele llamar hierofanía. La forma de pareidolia, en arquitectura y urbanismo es más sencilla. Asumimos un cuadrángulo de ángulos sensiblemente rectos y lados aparentemente iguales y le llamamos cuadrado, podemos aproximarnos a un círculo y lo llamaremos como tal. A mayor complejidad de la forma, mayor dificultad para asignarles una forma simple, lo que podría llevar a una "crisis

\footnotetext{
Francis Ching: Arquitectura forma, espacio y orden (1982).

Araujo, Ignacio, La forma arquitectónica (1974).

Por experiencias previas, la reverberación u opacidad sonora nos anuncia el tamaño de un espacio.

8 Queremos aclarar el uso de la palabra estética. Con ella nos referiremos, primariamente, a la búsqueda consciente de la sublimación de los actos humanos (aún de la misma percepción). No necesariamente a la belleza en cuanto tal. En tal sentido, consideramos que no existe estética en la naturaleza, en cuanto tal, sino tan solo belleza. Es posible que en el acto perceptivo-intelectivo de esa belleza, sí haya una forma de estética, en tanto búsqueda de sublimación consciente de tal belleza.
} 
perceptiva" que impediría una apreciación estética de la búsqueda de sublimación. No obstante, si presenta simetría especular, es más sencilla aprehender esa forma, porque se puede referenciar sus puntos y hasta líneas con las simétricas. Por supuesto que si la simetría no solo es axialmente especular, sino biaxialmente especular, es mejor. Es el caso de los caleidoscopios, que forman figuras que, por aleatorias que sean, nos parecen bellas $y$ con "patrones" reconocibles.

En el barroco se usó (y hasta abusó) de espacio de formas complejas, pero Borromini era capaz de diseñar espacios muy complejos que resultaban, no solo estéticos, sino, además comprensibles. Ver la planta de la iglesia de Sant'lvo alla Sapienza en Roma. Similar ejemplo es la Piazza di San Ignazio, también en Roma, tal vez el espacio urbano barroco complejo más puro que, no siendo rigorosamente simétrico, se percibe como tal. Por ello la forma debe ser perceptible como una unidad, aunque para abarcarla tengamos vistas parciales de ella.

Así, siguiendo a Araujo (1974) los elementos esenciales de la forma en arquitectura son la masa, que, para este caso, llamamos también limitante, el espacio y la superficie.

Llegamos a un tercer principio. Como hábitat, la calidad de un espacio está dada por las cualidades de los elementos que lo limitan -masa-y de aquello que los relaciona-superficiey que, parafraseando a Brandi (2008), sirve para la epifanía de la masa. Esos tres elementos esenciales de la arquitectura -masa, espacio y superficie- tienen forma. Las cualidades de estas formas (que terminan conformando a la ciudad) están en relación directa, entonces, con la calidad de la arquitectura y de la ciudad. Por lo que hemos visto, estas cualidades que la forma, en arquitectura y urbanismo, son las dimensiones, la proporción, la escala, el ritmo, la textura, el color y la reconocibilidad. En términos más complejos y para ciudades, Kevin Lynch" llamó a esta "reconocibilidad" con el nombre de "imaginabilidad", que es la cualidad de una ciudad o sector urbano por el cual hallamos identidad o la diferenciamos de otra y la reconocemos como tal ciudad.

Según León Bautista Alberti ${ }^{10}$ (De Re AEdificatoria) la ciudad es como una casa grande. Esta es una de las razones por las que hemos comenzado el presente trabajo, viendo más arquitectura que ciudad. La otra es porque no hay forma de conformar el espacio urbano sin arquitectura. Aún más no hay, y no puede haber ciudad sin arquitectura. Pero lo que vemos de las arquitecturas de una ciudad es solo y únicamente, las masas y superficies exteriores que definen su forma externa. En tal sentido, el trabajo de un arquitecto no puede ocultarse. Está sujeto a la crítica pública.

Sobre la base de lo anterior, podemos decir que, al igual que la arquitectura, la ciudad es, ante todo, espacios y, por lo tanto, limitantes y texturas. Pero, a diferencia de la arquitectura, cuyos limitantes son, todos, expresamente construidos, dimensionados, escalados, ubicados, proporcionados, texturados, coloreados, etc., en un proyecto integral único, en la ciudad, los espacios están, casi siempre, conformados por la arquitectura que, diversos proyectistas han realizado en la misma época o en diversas. Los espacios urbanos son "contenidos" por la arquitectura que conforma la ciudad. No son las calles, las plazas, los bulevares, trazados en el plano, y luego en el piso, los que crean los espacios sino muy al contrario son las arquitecturas, ubicadas y distanciadas según ese plano previo, las que "crean" esos espacios urbanos, porque el plano solo nos da dos dimensiones. En la casa, sobre el trazado bidimensional, se edifican los limitantes, que tridimensionan el espacio. Las arquitecturas, con sus formas y dimensiones, le dan a los espacios urbanos sus características. Pero debemos insistir que, mientras que en arquitectura, lo que se edifica se hace con la clara y expresa intensión de limitar el espacio y crear la arquitectura, en las ciudades, salvo honrosas excepciones, las arquitecturas se construyen con la finalidad de ser arquitectura y de cumplir las funciones para las que se

\footnotetext{
9 Lynch, Kevin. La imagen de la ciudad. (1974).

10 Filósofo, jurista, político, pintor, escultor y arquitecto humanista del s. XV.
} 
conciben, no de crear espacios en la ciudad. Esto último es un subproducto en casi todos los casos. Los espacios se conforman porque se hace arquitectura sin la consciencia de que se están conformando. Ello obedece a múltiples factores. A esta conformación de espacios con la arquitectura como limitante, Spreiregen (1971) le llama "cerramientos" y consideraba que era la clave del espacio urbano limitado y contenido de las ciudades tradicionales, con las que Spreiregen se identifica.

Podemos tener un cuarto principio. Las calidades de las arquitecturas definirán, en gran parte, la calidad del espacio de la ciudad o de porciones de ésta. Esto, desde su postura muy neoclásica, es algo que el arquitecto luxemburgués Rob Krier (1981) ha trabajado ${ }^{11}$. Krier dice que, a diferencia de los antiguos arquitectos, los contemporáneos obvian esa responsabilidad, que estuvo presente hasta la renovación de París por Napoleón III y su prefecto, el barón Hausmann, por lo que esa ciudad tiene la calidad que puede exhibir. Pero la calidad del espacio público urbano se basa, también en la calidad de las interacciones del espacio creado con su entorno infraestructural y social, tanto inmediatos como mediatos.

Krier, quien conjuntamente con su hermano Leon, ha realizado trabajos de "reinvención urbana", sobre todo en Stuttgart, ha buscado devolver a los espacios urbanos la calidez que tenían antaño procediendo como Bernini en la definición del espacio de la Plaza de San Pedro de El Vaticano ${ }^{12}$. Considera que en el siglo XX se produjo la destrucción del espacio urbano, y no precisamente por las guerras. Ha realizado un estudio sobre la necesidad de reconocimiento geométrico de los espacios, tanto calles como plazas, a las que considera el centro de observación de la ciudad (y que son el foco de atención de sus trabajos como proyectista urbano $\mathrm{o}$, mejor expresado, de "arquitector" urbano). Pero son las plazas las que deben tener una definición perceptiva por parte del observador, es decir, ser netamente percibidas con una forma conocida y reconocible: triángulo, trapecio, cuadrado, rectángulo, círculo u óvalo. Obviamente es la arquitectura (el limitante, como llamamos en este trabajo) la que produce esta definición geométrica.

Para Krier, primero fue la plaza, la que resulta de la agrupación de las casas alrededor de un centro, de un espacio libre en el que, según creemos estaba el tótem y el fuego tribal y, luego, cuando esta agrupación se satura se generan extensiones o crecimientos de la ciudad mediante alargamientos que vienen a ser las calles.

Ortega y Gasset (1950) afirma que la ciudad es "... plazuela, foro, ágora. Lugar para la conversación, la disputa, la elocuencia, la política".

Sin embargo queremos aclarar, sin oponernos a Krier, que la plaza a la que él se refiere es, meramente, la plaza que nosotros denominamos tribal o inicial, no tiene la connotación de plaza mayor iberoamericana, que será nuestro principal punto de atención.

Al decir que las arquitecturas de la ciudad conformaban los espacios de ésta, no hemos sido categóricos, pues hay, evidentemente, elementos naturales que también lo hacen, como acantilados, ríos, mar, montañas, bosques, lagunas o humedales que han sido respetados. Son elementos tan contundentes que, obviamente, "marcan" el espacio, lo conforman.

Tampoco hemos sido contundentes al afirmar que la estética de una ciudad se deba a la calidad de la arquitectura. Hay elementos que coadyuvan a esa estética como los mencionados en el párrafo anterior y su aprovechamiento, pero también elementos artificiales como bosques urbanos no naturales, fuentes, esculturas urbanas (monumentos), puentes, etc. que darán belleza y /o carácter

11 Tanto en su libro El espacio urbano (1981), como en sus obras, en las "reinvenciones" (como él mismo las llama) de extensos sectores de la ciudad alemana Stuttgart.

12 Hacemos esta referencia porque la plaza de San Pedro está rodeada de una columnata sin aparente utilidad, que conforma un óvalo. Esta columnata es un pórtico cuádruple que es usado como protección contra el sol y la lluvia. Ese criterio humano de la ciudad es rescatado por Krier en sus obras. 
a la ciudad o porciones de ella. A esta búsqueda de estética urbana le llamaremos paisaje urbano. Para Cullen ${ }^{13}(1974)$ el trabajo del paisaje urbano (townscape) puede dar sentido, significado y estética, al espacio conformado por algunos edificios inconexos o "embrollados", mediante el manejo consciente de texturas de piso, escala, etc. de tal manera que quienes viven, trabajan, o simplemente lo contemplan, se sientan satisfechos. Lo que propone Cullen es casi el trabajo de inscape, o decoración, o arquitectura de interiores, en los grandes espacios libres, lofts, ${ }^{14}$ como en los ex edificios industriales o de oficinas que son habilitados para viviendas.

No obstante, y en ello queremos ser claros, si el espacio urbano está bien conformado, con buenos ejemplos de arquitectura, serán necesarios pocos esfuerzos, y no se requerirá de "soluciones heroicas" para lograr un magnífico paisaje urbano o una excelente estética urbana. No nos estamos refiriendo a edificaciones de un estilo único. Pueden ser de diversos estilos que conjuguen entre sí, como sucede en Roma, en París, en Cusco, o Bologna, por poner solo unos ejemplos, como si se tratase de un "bric a brac"15 urbano, que en realidad evidencia la historia urbana.

El aspecto cinético no lo dejaremos de lado. Las personas y los vehículos afectan la percepción de la estética urbana. Una aglomeración de vehículos y el ruido que provocan, deturpan el paisaje por afectar a la percepción o por llamar la atención más que aquello que se desea que se aprecie. Excepto que el espacio haya sido creado para ese cientismo y cantidad de personas o vehículos. No nos imaginamos una Highway o una Superstrada sin vehículos, se las sentiría desiertas. Si volvemos a la metáfora de la ciudad, como la "gran casa", podemos ver que cada espacio urbano fue concebido para funciones determinadas.

\section{El espacio en la ciudad}

Para Chueca (1991 p. 14) "la casa, la calle, la plaza, los edificios públicos y los límites que la definen dentro de su emplazamiento espacial (todos estos elementos obedecen) a una concepción unitaria". En sentido lato de la frase, estamos de acuerdo con Chueca, pero en sentido estricto, no.

Así como en una casa hay servicios higiénicos, cocina, espacios de estar, de circular y de distribución, patios, terrazas y jardines, así, en la ciudad, hay espacios para estar, espacios para congregarse, espacios para circular, espacios de distribución, hay patios, terrazas, y jardines.

Así como en una casa no se debe confundir la función de un jardín con la de un patio, en una ciudad no se puede confundir la función de un parque, o peor aún, de un bosque urbano o de un jardín urbano, con el de una plaza.

Así como en una casa a nadie, en su sano juicio, se le ocurriría construir en una terraza, en una ciudad, a nadie se le debería ocurrir -o si se le ocurriese, no se le debería permitirconstruir en un malecón, que es una terraza urbana, pues la terraza perdería su cualidad de tal.

Si bien la función de un espacio es relativa a la coyuntura temporal, un jardín, por alguna determinada razón puede ser sacrificado para dar paso a un patio (o viceversa, cuando este patio ya no es útil como tal), lo común es que los espacios sirvan para lo que se crearon. Lo mismo sucede en la ciudad. Igualmente, si en una casa consideramos inaceptable sacrificar nuestro jardín, tal vez pequeño o el único de la casa, para convertirlo en un espacio árido, así, debe resultar inaceptable que porciones abiertas de la ciudad, que permiten el desahogo, sean

13 Cullen, Gordon, El paisaje urbano. Tratado de estética urbanística. (1974).

14 Los lofts, tuvieron su origen en Nueva York de los años 50 del sXX, en los barrios del Soho y otros en los que el alto precio de los inmuebles y la decadencia de ciertas zonas industriales llevaron a la utilización de aquellos edificios con grandes espacios y enormes alturas, como vivienda, en una especie de renovación urbana. Por lo tanto eran espacios con columnas muy espaciadas como para las máquinas fabriles.

15 El bric a brac es un estilo de origen francés que surge de la colocación de objetos valiosos, aunque de diversos estilos, usados para decorar y ambientar, sobre todo, aunque no únicamente, chimeneas u otros y que, sólitamente, son testimonios de la historia familiar o simplemente de colección. 
convertidas en espacios cerrados, por lo general por arquitecturas de dudosa calidad.

Un jardín, en una casa, tiene la función de embellecer las visuales desde el interior, a través de una ventana o de una puerta abierta. Este último ejemplo es clásico en la arquitectura tradicional japonesa, cuando el árbol de cerezo (sakura) está en su máxima belleza, durante su efímera floración, o el arce japonés (Acer japonica rubra) está otoñalmente teñido de rojo; en ambos casos es un espectáculo para la vista, y se discurre una de las paredes de papel de arroz para que los anfitriones y los invitados -especialmente para ese espectáculo- gocen con la vista. También sirve de desahogo, tanto visual como de renovación de aire. Así en una ciudad, ésa es la función de un parque o de un jardín urbano. Se debe pensar en la belleza $y$ en el beneficio ambiental que producen. Diversamente, un bosque urbano tiene como función primordial, el intercambio $\mathrm{CO}_{2}-\mathrm{O}_{2}$ y el "filtrado" del polvo o partículas en suspensión en el aire. Pavimentar un jardín urbano o un bosque urbano, o hacerlo en exceso en un parque, es negativo.

En una casa, los patios cumplen funciones utilitarias y, en menor medida, estéticas. Un patio sirve para tender la ropa a secar, si es tendal; sirve de lugar de paso y donde se encuentra el lavadero de los estropajos y "trapeadores" (o fregonas), si es un patio de servicio; sirve para colocar poyos y una pileta; si es de estar, sirve para ubicar una parrilla o un horno de barro, si está adyacente a la cocina y a la zona social, para fiestas. Así, en una ciudad, plazas, plazuelas y plazoletas cumplen estas funciones y actividades urbanas. Si ajardinásemos nuestros patios en las casas, no podremos usarlos para la función que fueron concebidos, o estropeamos el ajardinado, el césped o las plantas y flores. Igualmente, ajardinar plazas, plazoletas o plazuelas, es un error que, no obstante, se comete muy frecuentemente en nuestro medio peruano.
Pero veamos los tipos de plazas a las que, frecuentemente accedemos. En orden de importancia tenemos a) plaza mayor; b) plaza barrial; c) plaza de armas; d) plaza cívica; e) plaza religiosa; f) plaza ordenadora del tránsito; g) plazuela y k) plazoleta.

a) Las plazas mayores son un constructo urbano moderno que, en España data de 1480 con una ordenanza de los Reyes Católicos en la que se prevé, para las ciudades de reconquista, una plaza, lo suficientemente amplia como para que se instale -diariamente, pero por horas, por cierto-el mercado y se ubique la casa consistorial o casa del ayuntamiento. Pero el concepto que se manejó luego fue diferente, debido a la forma, ya no de reconquistar, sino de conquistar $y$, por lo tanto, a las ciudades de conquista. Ello data, en América desde la conquista de México y se refuerza con la conquista del Perú, y la fundación española de la ciudad de México y las correspondientes del Perú (Cajamarca, Cusco, Lima o Ciudad de los Reyes) en la $3^{\text {a }}$ $4^{\mathrm{a}}$ décadas del s. XVI, respectivamente. En ellas fue absolutamente necesario desacatar las ordenanzas de Carlos V y de su Hijo, Felipe II en las que se instruía que no se fundasen ciudades sobre las de los naturales; que la plaza tuviese una proporción de $2 \times 3$ y que en ella estuviese el mercado y el ayuntamiento mas no la iglesia ni la casa cural. En la fundación de las ciudades mencionadas fue necesario hacer sentir el dominio de los conquistadores asentándose, posándose, sobre los naturales y posesionándose de los lugares importantes de estos con edificios de similar vocación. Sobre el palacio o huaca del curaca se colocó el palacio del gobernador o similar; sobre el edificio religioso se colocó una iglesia (luego, posiblemente catedral). Así, se estableció una forma-concepto de plaza mayor que incluía, como entre los naturales, edificios cívicos, religiosos y de servicios, así como usos simbólicos ${ }^{16}$. Ello se estableció en la península entre fines del s. XVI e inicios del s. XVII, luego de la experiencia en América.

16 En el Perú, desde tiempos muy tempranos se puede ver ese esquema, con las huacas llamadas "en forma de U". Los españoles se las encontraron en Cajamarca, Cusco, Vilcashuamán, Lima, etc. Sobre ellas superpusieron sus plazas y, sobre los edificios importantes, sus símiles hispanos. En el caso de Lima, sobre el templo de Sinchi Puma, se ubicó la catedral; sobre la huaca -casa de Tauli Chusco, se ubicó el palacio del gobernador, luego de los virreyes y hoy Palacio de Gobierno. En el caso de Cusco, sucedió igual, incluso, sobre el Aclla Wasi se ubicó la casa de las vírgenes (religiosas) de Santa Catalina. En tal sentido, el vivir en, o más cerca de, la plaza, o alejado de ella, era significado de tener un mayor o menor estatus. Aseveramos que en España no existía un concepto tal de plaza hasta luego de la conquista. 
Las plazas americanas prehispánicas solían tener dimensiones desconocidas para el estándar europeo de las plazas mayores en las ciudades medievales. Si consideramos que las plazas mayores españolas, entre medievales y modernas tienen medidas, por demás modestas, por ejemplo y en cifras redondas, Madrid, $119 \mathrm{~m}$ x $80 \mathrm{~m}$; Valladolid $123 \mathrm{~m}$ x 82 m; plaza de María Pita (A Coruña) 110 m x 100 m; Cáceres, 148 m x 47 m. Mientras que en América algunas plazas mayores de fundación tienen las siguientes medidas redondas ${ }^{17}$ : Lima, 137 m x 137 m; Cusco 160 m x 108 m; Ayacucho, $130 \mathrm{~m}$ x $130 \mathrm{~m}$; Cajamarca, $147 \mathrm{~m}$ x 130 m; Huánuco, 126 m x 123 m; Trujillo, 152 m x 146 m; Ciudad de México, 240 $\mathrm{m} \times 196 \mathrm{~m}$. A ello debemos considerar que las plazas prehispánicas tenían dimensiones colosalmente mayores. La longitud de la plaza cusqueña de Huacaypata $^{18}$ - Cusipata tenía una longitud superior a los $450 \mathrm{~m}$. La razón es la polifuncionalidad de las plazas mayores de la conquista. En todos los casos reúne poderes civil, religioso y comercial. En Huánuco Pampa las dimensiones son de $350 \mathrm{~m}$ x $500 \mathrm{~m}$.

b) Las plazas barriales son aquellas alrededor de las cuales se han formado ciertos barrios, como en el caso de las Reducciones Toledanas, que se conformaban alrededor de una plaza, como en El Cercado o en Moserrate, ambas en Lima. De estas sí hubieron en la Península, aunque no con el carácter con el que se hicieron en la América conquistada. Estas plazas, como casi todas, servían para la congregación de la población y para uso de mercado (tianguis o kat; castellanizando la palabra, el virrey Toledo la llamó "gato"). Podían ser grandes o pequeñas, con forma cuadrangular, pero como estos barrios no tenían el rigor de la trama en damero a escuadra, podían ser, o no, necesariamente, rectangulares. Juan de Matienzo, quien acompañó al virrey las describió así:

Una plaza de forma cuadrangular en el centro y luego manzanas cuadradas que se dividirían en cuatro solares por lado y sus calles anchas. La iglesia se fabricaría en una de las cuadras o manzanas de la plaza; a su frente mesón para los españoles que estuvieran de paso en dicho pueblo, y que comprendería cuatro cuartos con techos de tejas y con caballerizos; en uno de los solares de la otra cuadra se levantarán la casa del Cabildo, en otra se edificará el hospital; en el otro la huerta y servicio del hospital; finalmente en el último solar, corral del Cabildo. En uno de los solares, de las cuatro manzanas que rodean la plaza, se construirá la casa del corregidor; detrás de esta casa para el Tucuy Ricuy y cárcel, en la que habría dos cepos y cuatro pares de grillos y dos cadenas.

c) Las plazas de armas eran las que se ubicaban inmediatamente después de la puerta de ingreso a una ciudad amurallada. Eran como el espacio de ordenamiento, revisión y repartición de quienes podían llevar carga. Funcionaban como los vestíbulos o los lobbies de los edificios contemporáneos, pero también como aduana. Usualmente estaban cercanas a escaleras a las murallas y adyacentes a las puertas, como se dijo, por eso era el lugar en donde se juntaban las armas para defender la ciudad. De allí su nombre. Una ciudad podía tener varias plazas de este tipo, como las plazas de San Pedro y de Santiago en Lugo, por ejemplo.

d) Plazas cívicas, son aquellas que se formaron para conmemorar un hecho cívico patriótico o a un héroe. Su razón de ser es esta dedicación y la congregación de ciudadanos con la finalidad de loar al héroe. La plaza San Martín o la Plaza Manco Cápac son muestra de ello. Su historia no data de antiguo, es tan reciente como el concepto de patria y héroe patrio cuya efigie o monumento conmemorativo debe estar al interior de ella.

e) Plaza religiosa, similar anterior, pero de orientación a lo religioso. Servía para reuniones

17 Las dimensiones son en puntos medios, al tener formas cuadrangulares, aparentemente cuadradas, pero, en realidad, de forma trapezoidal.

18 En adelante usaremos la palabra Huacaypata, que fue como siempre se le conoció (lugar donde se llora) en vez de Aucaypata (lugar del guerrero) que es como ahora grandes sectores de la población cusqueña le llama, por la idea de que los incas no lloraban. 
religiosas, como misas al exterior, inicio de procesiones (como la del Señor de Luren, en Ica) $\mathrm{u}$ otros actos religiosos (como la Plaza de San Pedro en El Vaticano) o, en Lima, la Plaza de la Inquisición o la plaza Italia. Es obvio que alrededor de una de estas plazas debe haber, al menos un edificio religioso.

f) Plaza ordenadora de tránsito. Ejemplos clásicos de este tipo de espacios urbanos son los óvalos y las plazas circulares, que sirven, primordialmente, para ordenar el tráfico vehicular en un encuentro de dos o más calles, aunque luego se les coloque al interior un monumento conmemorativo. Esto se inició con los llamados Rond point, en el urbanismo de la renovación de París en el Segundo Imperio (Napoleón III y el barón Haussmann). En nuestro medio están las plazas Bolognesi, 2 de Mayo y Unión. Fácilmente se puede ver que no son usadas por los peatones en la zona central, excepto en las fechas en las que se conmemora el hecho que se evoca o al personaje que se loa. Con buena consciencia cívica y con el conocimiento cabal del reglamento de tránsito (y su cumplimiento) las formas que asumen estas plazas hacen que cumplan muy bien con su cometido.

g) Plazuelas, son espacios públicos urbanos que, generalmente, aunque no siempre, se hallan frente al atrio de una iglesia o se trata de un atrio muy grande. Su uso, vecinal, es más de estar y solían tener algunos árboles. Sus dimensiones son pequeñas y generalmente están en una de las esquinas de una manzana.

h) Plazoletas son espacios duros en parques o jardines urbanos, que sirven para ciertas actividades asociadas al uso del parque. Su tamaño depende de las funciones a las que está destinada. No se debe confundir con las plazuelas.

\section{UN POCO DE HISTORIA}

Aunque no esté demostrado, resulta plausible pensar que las plazas se originaron en el espacio tribal del fuego sagrado, del fuego de reunión de los habitantes, aquel espacio en el que los ancianos narraban a los más jóvenes la historia (totémica, tal vez) del pueblo; ese espacio en el que se reunían para tomar decisiones y para partir a la guerra. No es descabellado pensar en ese origen, ni difícil imaginárselo.

Pero donde ese espacio adquiere carta de ciudadanía es en Grecia, donde el ágora resulta ser el lugar de reunión de los ciudadanos, donde se discute y hace política, es decir, donde se gobierna la "polis", la ciudad. En Atenas estaba circundada ${ }^{19}$ por edificios religiosos y cívicos, pero sin constreñir el espacio a una forma clara, ni demarcándolo de manera cerrada. Habían, además las "stoas" o portales que no estaban adosados a manzana alguna sino que eran edificios separados. Era como un caos orgánico que obedecía al trmenos ${ }^{20}$ del lugar. El ágora de Atenas, por ejemplo, tenía algunos edificios en su área y era atravesado por la calle Panatenaika.

En la ruta clásica, le sigue Roma, donde las plazas adquieren el nombre de foro. En una ciudad solían haber varios. En ciudades de planta nueva o en renovaciones o desarrollos planificados, estos foros solían ser cuadrangulares y equivaler a una manzana. Si se trataba del foro principal, estaba rodeado de edificios religiosos (templo), de decisión (la curia), el mercado (como edificio) y otros. La ciudad bizantina de Constantinopla (hoy Estambul) tenía varios foros sucesivos antes de llegar al más importante o Augusteo. Espacio urbano cerrado que estaba rodeado por el Milión o puerta de ingreso a la "Ciudad Sagrada" (a la que se llegaba por la Mese o avenida principal y que atravesaba los foros previos, llamados de Arcadio, Boario, de Teodosio y de Constantino); también lo rodeaba el Palacio imperial; el Senado y la Iglesia de Santa Sofía. Salvo por la función comercial se puede decir que, junto con el foro romano, son verdaderas plazas mayores, rodeados de portales.

\footnotetext{
19 Usamos el término circundar, porque no estaban dispuestos formando una figura conocida.

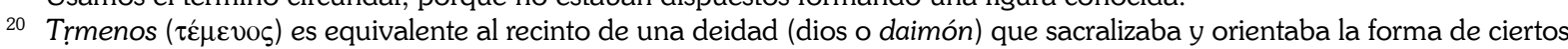
espacios.
} 
En la Alta Edad Media, se pierde casi por completo el concepto de ciudad y, por lo tanto de plazas, subsistiendo, cierta idea de ellas en los castillos en el patio de honor y el patio de armas. Pero, desde la plena Edad Media y sobre todo desde la baja Edad Media y el renacer de las ciudades, las plazas vuelven a ser consideradas, aunque no se las planifique. Se trata de simples espacios remanentes o ensanches de algunas vías, las mismas que, a falta de una edificación para tal función como en los foros de Roma ${ }^{21}$, fungían de mercados, bien sea como plazas del ayuntamiento o como plazas religiosas. No se solía juntar ambas funciones. Esta tradición siguió durante el Renacimiento. Aún en lo más semejante, como en las bastidas, en Francia, y las ciudades de reconquista, en España, en las que sobre una traza reticular, se reservaba un espacio para la plaza, la misma que era totalmente porticada incluso en las esquinas, por lo que es perceptivamente cerrada, no obstante no estaba el edificio religioso. Lo peculiar de estas plazas es que tenían los llamado cornieres, que eran un pequeño ochavo en cada esquina, también con portales.

En las grandes culturas de América, grandes edificios de gobierno y religiosos conformaban un espacio muy grande. Lo usual es que lo hicieran por tres lados, dejando el otro, sea orientado al entorno natural o cerrado con un muro y un vano hacia lo natural. Eran espacios solemnemente ceremoniales en el que participaban activamente los caciques $y$ los sumos sacerdotes, pero al que solía acceder el pueblo llano. Y esa es la razón por la que debían tener esas dimensiones colosales.

Durante el humanismo renacentista se descubre y conquista América y el choque de la cultura española con las grandes culturas indoamericanas produjo esa nueva forma de plazas mayores en las que se reunieron todos los poderes, el civil, el religioso y el comercial, con una carga simbólica muy fuerte, de dominio, orden y civismo. Era el lugar de la comunicación ciudadana por excelencia, donde se leía por primera vez un bando (o decreto); donde se ajusticiaba a los delincuentes o subversivos; donde se hacían los autos de fe; se representaban los autos sacramentales; partían los ejércitos; se hacían corridas de toros y fiestas cívicas ${ }^{22}$; donde la gente se refugiaba luego de un terremoto o donde se capitulaba la rendición de una ciudad, donde se hacía las compras del mercado ("hacer la plaza") o donde se tomaba coches (o carros) de plaza ${ }^{23}$. En la plaza se realizaban los desfiles y las procesiones. En la plaza se obtenía agua. La plaza manifestaba la plasmación física del orden de la sociedad y, en ese orden, simbolizaba el espíritu en el que el sistema se funda.

Makowsky (1996) dice que “... la complejidad social tiene necesariamente su expresión material en la arquitectura $y$, en general, en el uso del espacio; a mayor complejidad, mayor diversidad de formas y funciones en la arquitectura, mayor envergadura en las construcciones". Por ello la plaza simboliza o significa, con claridad, su rol en la vida social urbana y la organización de esta.

De acuerdo a las Ordenanzas para la fundación de ciudades en el nuevo mundo, que mandó cumplir el emperador Carlos V en 1523, las nuevas ciudades debían fundarse lejos de los asentamientos de los naturales, debían de estar cerca a fuentes de agua; trazarse a cordel, en damero y reservar una manzana para la plaza; un lugar tal que permita el crecimiento continuo de la ciudad a partir de ella, encontrándose, por lo tanto en el comedio de la población. Debían tener una proporción de 2 x 3 y no estar en ella la iglesia. En el caso de Latinoamérica, es claro que eso no se cumplió. La plaza, además debía contar con la picota y el rollo, es decir, los símbolos de la justicia. En España, la Plaza Mayor de Madrid, cumple con la proporción y refleja su vinculación con

${ }_{21}$ Debemos considerar que se había perdido por completo la cultura ciudadana, la cultura de las ciudades, durante la Alta Edad Media.

22 En algunos casos, el del nacimiento de un infante o llegada de un nuevo virrey o arzobispo, con obras de arquitectura efímera.

23 Que luego serían los taxis, pero que en épocas anteriores a los automóviles, estaban los coches de a caballo alrededor de la plaza, costumbre que siguieron los motorizados. 
las plazas de las ciudades de reconquista (y de las bastidas francesas) por su cerramiento total con portales. La plaza de Madrid se comenzó a construir, recién en 1617.

"En la ciudad colonial el núcleo urbano se estructuraba siempre en torno a la plaza mayor, donde se ubicaban los principales edificios públicos. De acuerdo a la jerarquía de los vecinos se señalaba la distribución de los solares estando los más importantes próximos a la plaza." (Peralta y Samanez, 1993 p. 21). Debemos dejar claro que solo los españoles y criollos podían residir cerca a la plaza, pero los esclavos, indígenas fámulos de los vecinos de la plaza y aguateros podían acceder a ella para sacar agua de la fuente o sus pilones.

La función de mercado en nuestras plazas, se extendió también en la península, generando las denominadas catu, tianguis (palabra que vino de Mesoamérica, del náuatl tianquiztl y que algunos llamaron tiandez), o vico y en los portales se ubicaba el comercio más establecido y permanente, además de mayor movimiento comercial y que no podía ser "sobre ruedas". Son típicos los portales del Pan o portal de Mantas, etc.

La plaza era el punto de encuentro, la zona urbana social por excelencia y el punto de reunión de las expresiones religiosas de la comunidad, bien sea las procesiones, que en Perú fueron -y son- tan extendidas, por motivos de sincretismo religioso, o para autos de fe. En general, el espacio de la plaza, al ser todo de arena y no contar con jardines, era un espacio de uso urbano social, pudiéndose transitar a caballo.

Era el centro, tal vez no físico, pero sí significativo o simbólico. Esto continuó hasta fines del siglo XIX. Vale decir, hasta la aparición del automóvil y la construcción de edificios de mercado. Además, el gusto neoclásico le resta funciones, que son asumidos por edificios ad hoc y la vida pública, ciudadana, se pierde. Al perder funciones, se le colocan jardines y sirve "para dar un paseíto".

Hasta el momento de la república el "criterio de urbanización (...) obedecía a principios de carácter ideológico en los que la plaza mayor asumía un rol de primera importancia dentro de la vida de la ciudad centralizando en su espacio todas las actividades religiosas, políticas, económicas y administrativas, posibilitando, en consecuencia un control absoluto sobre la población conquistada" (Peralta y Samanez, 1993 p. 24)

El automóvil lleva a modificar las plazas mayores por múltiples razones. La primera es porque es necesario "abrirles paso" $y$, al entenderse como símbolo de la modernidad y del progreso, se le dio prioridad y preeminencia sobre los peatones. La segunda es porque el automóvil "acorta" distancias y las ciudades se descentralizan con los barrios suburbanos, los que tienen dinámicas propias, aunque para asuntos mayores se deba recurrir a "ir al centro".

La plaza pierde muchas funciones que le eran propias, pero su carga simbólica de centro del centro no la pierde, en ninguna de las ciudades. Sigue siendo, eso sí, el principio y medida del prestigio de los habitantes de la ciudad, hasta el derribo de las murallas. Su uso se vuelve más elitista y pierde sus funciones sociales urbanas de la época de la colonia

Al momento de la fundación de las ciudades, tanto las de reconquista, como las de conquista, no se hicieron necesarios espacios urbanos bajo el concepto de parque. La razón es que el entorno natural era bastante inmediato pues las ciudades eran muy pequeñas en comparación a las actuales. Además los solares solían ser de gran área porque cada manzana se dividió en cuatro, ello significaba, por ejemplo en el caso de Lima, lotes de $60 \times 60$. Con lo que todas las casas tenían un huerto en la parte posterior. Cuando la ciudad se expande y devora la campiña inmediata, se comienza a considerar la existencia de parques. En el caso del Perú, ello significó la introducción de jardines arbolados en casi todas las plazas mayores, restándoles capacidad funcional al área de la plaza en sí. Ello es algo que llegado hasta nosotros y se asume como algo natural y resulta casi impensable una plaza solo de piso duro. Es más, la Plaza San Martín fue diseñada con grandes extensiones de jardines, con bancas - 
que las plazas mayores no solían tener- y con piso de adoquines de piedra. Es decir, una plaza concebida, casi exclusivamente, para el estar y ocio urbano.

Los paseos se dan en los más actuales boulevares o en los paseos, de tipo más francés que español o latinoamericano.

\section{DOS CASOS}

\section{La Plaza Mayor de Cusco}

Siguiendo la larga tradición precolombina mesoamericana y sudamericana de grandes espacios urbanos rodeados de edificios importantes, bien sean con plazas a nivel o hundidas, la ciudad del Cusco contó con un excelente ejemplo en su trazado y en la resolución del Huacaypata-Cusipata, del tipo de plazas a nivel.

podremos afirmar que, el trazado reticular con un gran espacio central de convergencia del conjunto urbano, en que se desarrollan las actividades principales, fue aplicado en las ciudades precolombinas.

Si bien el espacio ${ }^{24}$ central ha sido fundamentalmente un espacio ceremonial, sus funciones la identifican como una plaza, en torno a la que se genera $y$ organiza la ciudad en su conjunto ${ }^{25}$. Esto posibilitó que estructuras urbanas con estas características fueran aprovechadas por los conquistadores españoles para establecer sus ciudades.

El ejemplo más elocuente es la ciudad del Qosqo antigua capital del Estado o imperio de los Incas.

En términos generales, las grandes líneas del urbanismo hispanoamericano según Levedan son: 1) Vinculación orgánica de las diversas partes de la villa y la subordinación a un centro; 2) la perspectiva monumental;
3) el programa ${ }^{26}$ Peralta y Samanez (1993, pp. 17 y 18$)$

Si bien concordamos con Peralta y Samanez en lo de la trama en cuadrícula, debemos ser objetivos y ver que, por la topografía, esa cuadrícula es, más bien, retícula pues los ángulos en $90^{\circ}$ no se cumplen. Considerando la arquitectura inca, es muy posible que el trazado siguiera (o tratara de hacerlo) su trazado ortogonal.

Al llegar los españoles, traían las especulaciones urbanísticas renacentistas que poco, o nada, tuvieron con el trazado cuadricular que sí, como hemos visto se dio en la edad media ibérica y sur francesa. En el renacimiento se jugó con formas regulares como los octógonos o hexágonos, como es el caso de Palmanova. El choque cultural entre los conquistadores y los naturales trajo como consecuencia las reminiscencias de las ciudades de reconquista, en este caso, de conquista, y con las mismas características de centralidad. Solo "calcan" de las culturas aborígenes la plurifuncionalidad de las plazas. La concentración de poderes en un único lugar.

En 1573, el 13 de julio, Felipe II dicta las Ordenanzas de descubrimiento, nuevapoblación y pacificación de las Indias, en las que, habida la experiencia previa, se considera a la plaza mayor como una suerte de empalizada o fuerte, de refugio final, casi una "torre del homenaje". Sin embargo, ya el virrey Toledo, entre 1569 y 1581, crea las reducciones de indios, las que tenían plaza mayor, iglesia, cabildo y solares, organizados alrededor de ella.

Al parecer, la primitiva ciudad inca del Cusco, se ubicó donde estaba el pueblo Acamama y se inició en Inticancha, lugar que luego se convertiría en Koricancha.

Su consolidación se dio luego de que Cusi Yupanqui o Pachacútec Inca Yupanqui le dio la forma del tótem terrestre, el puma.

${ }^{24}$ En negritas en el original.

25 Está clara la relación de la plaza con su entorno mediato e inmediato como lo hemos dicho. (Vid supra).

26 “.... El programa no es más que eso: la idea elemental a partir de la cual ese organismo vivo que es la ciudad va a modelar su forma dialéctica entre programa y modelado, la prueba de que una ciudad es cosa viva y que su diseño no es un ejercicio abstracto. Al fundar una ciudad, se engendra un ser que va a tener vida propia y a veces distinta a la que pensaron sus creadores." Rojas Mix, Miguel (1978) cit. Por Peralta y Samanez (1993) p. 18. 
En esta "totemización" -de un puma echado- Sacsayhuamán era la cabeza, y, la actual Pumacchupan, era la cola. La plaza de Huacaypata-Cusipata era el corazón (entendiendo por corazón, todas las entrañas, que era, siguiendo a Quezada (2007), con lo que se creía que se pensaba) y, el origen, el Koricancha fue, o simbolizó, los testículos. La plaza fue el símbolo del centro, las entrañas del Imperio, del conglomerado de los pueblos que lo conformaron; la "piedra miliaria" desde la que se medían las distancias; el lugar de partida, pero de eterno retorno y anexión.

Entonces, el Koricancha era importante por ser el origen, desde donde trazaron las sukankas y los ceques, pero la plaza fue el lugar desde donde se pensaba, se hacía política. La plaza estaba planeada como una dualidad complementaria o mitades de oposición complementaria, es decir, un par dialéctico. Siendo un solo espacio, en realidad eran dos, divididos, pero no separados, por el río Shapi o Huatanay (por eso le llamamos HuacaypataCusipata) ${ }^{27}$. En Huacaypata se celebraban ritos religiosos y marciales. En su perímetro había varios templos y palacios-templo donde se veneraban las momias de los anteriores incas, a cargo de sus panacas (o ayllus ${ }^{28}$ reales), estaba, también el Acllawasi o casa de las escogidas y el Yachaywasi o casa de la enseñanza, casi como una universidad donde se formaban los futuros administradores del Imperio.

En medio de la plaza, según los primeros cronistas, estaba el Usno. Este era una piedraaltar que, en diferentes sitios, adoratorios $y$ ciudades, tenía formas diferentes, pero que tenían la cualidad de huaca o cosa sagrada. En el caso de Cusco era una piedra con forma de teta (según Pedro Pizarro) o de Pan de Azucar ${ }^{29}$ (Juan de Betanzos), que estaba rodeada, a guisa de cinturón, por oro y piedras preciosas o semipreciosas. Alrededor de este Usno había una especie de alberca donde se bañaba el trueno, según varios cronistas. Tal vez funcionaba como un pararrayos. Nuevamente esto nos indica una dualidad: el puma o poma (la forma de la ciudad) era el tótem supremo de la tierra; el trueno Illapa era el tótem supremo del agua. Sobre esta piedra se derramaban las ofrendas y se ofrecían al dios Sol (Inti, como astro y Punchao, como divinidad del cielo). Esta idea de un elemento vertical, masculino en, o dentro de, un espacio rehundido, o femenino, es una constante en la cosmovisión andina, en general.

Además, la cuatripartición (que daba nombre a Tawantinsuyo) estaba presente, pues el cruce de los caminos que dividían el imperio en cuatro suyos, estaba en la misma plaza. Se trataba de los máximos ejes del Qapac Nan o red de caminos reales. Es decir, de la misma plaza se partía al Antisuyo, al este, al Collasuyo al sur, Chinchaysuyo, al norte y Contisuyo, al oeste, y el Cusco, su plaza era el centro. De la misma forma que los foros romanos, que estaban bordeados por el Cardo Máximo y el Decumano Máximo ${ }^{30}$ y significaban el ordenamiento urbano en insulae, y el territorial en las centuriatio, los dos ejes del Qápac Nan evidenciaban la trama en malla y la partición territorial (y política) del Estado inca.

Esta red de caminos que pasaba por el Huacaypata-Cusipata, sensorialmente ortogonal, sobre todo el eje que iba de sur oeste a noreste, también dividía la ciudad en Hanan Qosco, o Alto Cusco y Urin Qosqo o bajo Cusco, lo que era una representación de los tres mundos: Hanan Pacha ${ }^{31}$ o mundo

${ }_{27}$ Huacaypata significa "el lugar donde se llora", mientras que Cusipata significa "el lugar donde se ríe o se goza". Los mismos nombres están indicando la oposición.

28 Los ayllus eran una organización básica del imperio inca que agrupaba a los miembros de una misma familia extendida, que compartían, además, un mismo tótem y una ascendencia común. No se trataba de una tribu o clan. Las panacas eran los ayllus reales que representaban los cuatro suyos en los que estaba dividido el imperio. De ellos debía salir el inca, el que, una vez fallecido dejaba su panaca al cuidado de su momia, como ancestro o mallqui.

29 Pensemos en el cerro carioca de Pan de Azucar, mezclémoslo imaginariamente con una "forma de teta" y nos podemos hacer una cierta idea de lo que se trataba.

30 Que dividían el territorio en 4 templi: los templum anticum dextrum, al noreste; el templum anticum sinistrum, al noroeste; el templum posticum dextrum, al sureste y el templum posticum sinistrum, al suroeste.

31 Pacha, en quechua no solo es tierra como aquello (espacio) en que se está, sino que a la vez es tiempo en el sentido de kayrns, no de Kronos. 
de arriba o del más allá, cielo; Kay Pacha o mundo de aquí, de los vivos o Uku Pacha o inframundo, Averno o mundo de los muertos.

Pero, dividido por el río Huatanay o Shapi, a la vez que por el eje que va del sureste al noroeste del Qapac Nan estaba, y con un tamaño que casi triplicaba al Huacaypata, el Cusipata, sector de la macroplaza concebida por Pachacútec como el lugar de la reciprocidad y del agasajo a los aliados. En este espacio el inca se reunía con los curacas con los que quería establecer alianzas, les daba de beber y de comer durante varios días y se entroncaba con ellos doblemente, el inca tomaba por esposa a una hija del curaca y este casaba con una escogida o hija del inca o casaba a su hija o hijo con un descendiente inca. Al mismo tiempo, se traía tierra de la zona del curaca y se depositaba en Huacaypata y de ella se sacaba un poco de tierra para la cancha o pata de la zona a anexar. Inicialmente, la plaza tenía una capa de una cuarta de espesor de arena traída del litoral de la costa. Si consideramos casi $4 \mathrm{Ha}$. de superficie, por $24 \mathrm{~cm}$ (hasta $48 \mathrm{~cm}$ ) de espesor y que todo fue traído a lomo de llama, cuya capacidad de carga es reducida, y de personas, se puede ver el enorme esfuerzo que significó cubrir el piso de la Huacaypata con arena fina de mar.

Cusipata tenía más relación con el agro que con la ciudad y era el limen entre la ciudad sagrada (que se encontraba entre los ríos Huatanay o Shapi -que ya estaba canalizado- y el Tullumayu y Sacsayhuamán y Pumacchupan) y los barrios periféricos de Carmencca, y otros que albergaban a toda la población que daba servicio a la nobleza de la ciudad sagrada. Además, Cusipata, tenía como límites, al norte, una andenería, más como limitante que como zona productiva, aunque había maizales. Además servía para que, gracias a su pendiente con caída hacia el Huatanay, sirviera como platea de expectación para los pobladores no nobles a los actos rituales que ocurrían en el Huacaypata.

La plaza era así el símbolo del imperio y centro del mundo. Era, además, la representación de la visión que los incas tenían de su Estado y su estructura religioso-militar, que se basaba en la lealtad de los súbditos, en el compromiso de estos con el Estado y del Estado para con ellos y su bienestar, en la reciprocidad total.

Esta visión se trastoca hacia fines de 1533 con la llegada de los españoles a la ciudad imperial, el 23 de marzo, Cusco es refundada como ciudad española. Esta nació superpuesta o, como preferimos decir, "posada" sobre el centro de poder del Imperio. Sobre cada elemento infraestructural significativo inca de la plaza de Aucaypata, los españoles posaron otro hispano con funciones semejantes para combatir el simbolismo primigenio, relegando, además, a los pobladores naturales a los barrios satélites y arrabales. Así, la ciudad se expandió sobre -y aún más allá- de las andenerías de cultivo paisajista. Por lo demás, toda la ciudad respetó las calles (en algunos casos cercenando edificios) y su anchura, así como la plaza y las plazuelas, como la de San Blas que era existente y conocido con el nombre de Tococachi, de uno de los arrabales de personal de servicio agrupados por oficios o gremios, como lo era, también, Carmencca, hoy Santa Ana. Intipampa era la actual plazuela de Santo Domingo

Pero veamos que no fue la primera vez que en el territorio nuclear del Cusco ocurrió algo así:

En el lugar e sitio que hoy dizen y llaman la gran ciudad del Cusco en la provincia del Pirú, en los tiempos antiguos antes que en él hubiesen señores orejones Ingas Ccapac Cuna que ellos dicen reyes, había un pueblo pequeño de hasta treinta casas pequeñas pajizas y ruines y en ellas había treinta indios y el señor cacique deste pueblo se llamaba Alcavica y lo demás de entorno deste pueblo pequeño era una ciénaga de junco hierba cortadera la cual ciénaga causaba los manantiales de agua que de la sierra y lugar do agora es la fortaleza..." y continúa "...y así mismo era ciénaga en el lugar y sitio do en esta ciudad de la parte del arroyo (río Huatanay o Shapi) que por medio della pasa el mercado (tiandez) plaza de contratación de los mismos naturales indios. Betanzos (1551 (1987) Cap. III). 
Con lo que los españoles no se avinieron fue con la grandiosidad teocrática del espacio de la Huacaypata-Cusipata. Así, llegaron a dividirla, en 1555, por orden del capitán Sebastián Garcilaso de la Vega (padre del cronista) con una manzana de casas, sobre el río Huatanay. Con esta intervención consiguieron, además, alejar la mirada de los naturales desde "su" plaza-palco. Se creó así la plaza del Regocijo (que no por casualidad, tiene que ver con "lugar donde se ríe o goza". A su vez, esta plaza se dividió con otra manzana, aún más grande que la anterior, generando la plaza San Francisco. Imaginemos el colosal tamaño de Huacaypata-Cusipata. Podemos estimar el tamaño (fuera de las medidas que se pueden hacer con fotos aéreas o Google Earth) en 200 m x 500 m, como mínimo.

La catedral, cuyo primer obispo fue fray Vicente Valverde, se ubicó sobre el edificio religioso más importante de la plaza: el Kiswar Cancha, dedicado al Viracocha, el dios creador y ordenador del universo, de la luz, el cielo y la tierra, y del conocimiento, que envió a la tierra a través de su hijo Tunupa; sobre el templo Amaru Cancha, ligado a Unu Pachacuti, el gran diluvio del mundo, se edificó la iglesia de La Compañía de Jesús; sobre la casa de las escogidas o Acllawasi (casi "como el harem del inca", como dice Mariana Mould de Pease) se ubicó el Convento de Santa Catalina (esposas de Dios); entre las calles Suecia (antes Sucia) y Plateros, se encontraba el Ccasana, el palaciosantuario de Pachacútec el gran trastocador del mundo, y allí se ubicó Pizarro. El usno, fue reemplazado por el rollo y la picota, luego por una pileta de granito ala de mosca con 5 pilones. El eje monumental suroeste-noreste, del Qapac Ñan, se jalonó de iglesias y plazas, de noreste a suroeste están: San Blas (Iglesia y plazuela), iglesia del Triunfo, Plaza de Mayor, iglesia de La Compañía, Iglesia de La Merced, plaza del Regocijo; Plaza de San Francisco, iglesia de San Francisco, iglesia de Santa Clara, plazuela de San Pedro, iglesia de San Pedro.

La Plaza Mayor, luego de la conquista, se mantuvo sin mayores cambios, salvo ligeros cambios nada esenciales ni sustanciales. Llegada la república, siguió tal como se consolidó en el virreinato hasta el cuarto final del s. XIX. Se niveló y se retiró todo vestigio de la ocupación inca que quedaba en la zona central. Alrededor se construyó vías perimétricas, separadas de esta zona para el paso de los vehículos rompiéndose así la continuidad del piso de la plaza con los portales. La pileta, que proveía de agua dejó de ser necesaria y se la cambió por una de hierro fundido, más estética pero con un indio piel roja encima. Al crearse nuevos mercados, perdió su carácter de katu y se sembraron árboles y colocaron bancas.

En el s. XX se colocan los adoquines en las calles perimétricas, para el tráfico mayor de vehículos a combustión y se hace más duro el piso del área central, delimitando zonas de jardines y veredas como paseos. Las especies mayores, que son apropiadas en la zona, como el chachacomo (Escallonia resinosa), están en mal estado y debería haber un pisonay (Eritrina edulis) pero reduciendo el área de jardines que no son compatibles con la idea de plaza.

Pese a todos los cambios, la plaza mantiene su prestancia, calidad paisajista urbana y espacio urbano social, que logra integrarse con la arquitectura limitante y el paisaje montañoso circundante, con la iglesia de San Cristóbal, la de Santa Ana y el cerro Sacsayhuamán. La plaza es el recurrente lugar de encuentro de turistas, congregación de multitudes para las fiestas cívicas, patrióticas, políticas y religiosas. Su fuerza social se mantiene pese a los siglos.

La conformación de este doble entorno, el inmediato y el mediato, permite unas vistas extraordinarias que le dan a la plaza el sentido significante que tuvo y debe seguir teniendo. Desde los portales, nos presenta esa sensación existencial del aquí, el allí y el allá, como dice Cullen (1974). La vía suroeste-noreste que mencionamos nos presenta un conjunto de espacios articulados de manera magnífica, como menciona Norberg-Schultz (1975). Asimismo, desde el entorno se encuentran "puntos de amarre" en la forma de puntos focales, las torres, la pileta, el vacío de la plaza, etc. La plaza se yergue como el escenario que el gran teatro del mundo barroco forjó durante los siglos XVII y XVIII, conjuntamente con los terremotos. 
Pese a todo es lamentable que la plaza haya perdido, en su entorno inmediato, su carácter habitacional identitario, los pobladores son importantes en los espacios públicos, sobre todo en los de la jerarquía del Huacaypata. Los pobladores conforman la unidad paisajista de un espacio urbano, porque una ciudad no tiene sentido sin pobladores. Son estos los que hacen que una ciudad sea viva y posea historicidad, es decir, que, potencialmente, pueda crear o hacer historia y seguir siendo una ciudad histórica. Este carácter debería retomarse, si no en el perímetro de la plaza misma, al menos en las calles adyacentes. La presencia de pobladores, junto con el de las edificaciones periféricas y del entorno mediato, le otorga a los espacios públicos urbanos la función axiológica que identifica a las sociedades que pasaron y pasan por él.

El cruce de caminos, aún existente, pone en evidencia el orden físico, urbano y territorial, así como político del Imperio inca.

\section{La Plaza Mayor de Lima}

El territorio de Lima es interesante. Se trata de un oasis en el desierto. En un desierto que abarca toda la costa peruana y que es interrumpido por estos oasis que son formados por unos ríos de caudal estacional, generando valles productivos. Es lo que perfectamente podemos llamar "clima templado", salvo, por la humedad. Las temperaturas rara vez bajan de los $12^{\circ} \mathrm{C}$ o suben más de los $30^{\circ} \mathrm{C}^{32}$. La humedad sí es terrible, pudiéndose llegar, con cierta frecuencia al $100 \%$ y no bajar del $80 \%$, lo que potencia, tanto el frío, en invierno, como en calor en verano. Nunca llueve, solo hay una ligera llovizna a la que se le llama garúa. Está cerca del mar y de un puerto muy bien resguardado de los embates del mar. Eso atrajo a los conquistadores para asentar la capital en Lima.

Solo hay un "defecto" en Lima, y son los terremotos, eventualmente devastadores, como el de 1746, que vino seguido de un tsunami que arrasó, completamente, el puerto del Callao. El otro problema que, para algunos, tiene Lima, es que su cielo suele ser gris y estar sin sol. Podemos decir que en Lima sale sol 150 días al año, y no necesariamente todas las horas de luz. A unas personas eso les disgusta y a otras, esto nos parece una ventaja y estamos agradecidos por ello.

El territorio de Lima está bañado por tres ríos, siendo el más importante el central, llamado Rímac, con el Chillón, al norte y el Lurín, al sur. Está casi a la mitad de la costa peruana.

En esta área importante se formaron muchas culturas preincas, que fueron creando condiciones propicias para habitarla: Lima, Chancay e Ichma. Es excelente la palabra cultura para identificar a los pueblos que estuvieron antes del los incas, porque incluyó el culto a un dios, muy importante, llamado Pachacámac ${ }^{33}$, el dios de los temblores, uno de los dioses primigenios, junto Viracocha (su padre) y Kon, Vichama y Mallko. Estos dioses están presentes de una manera, o de otra, en todas las culturas andinas ${ }^{34}$ y en las diferentes mitologías están relacionados con la creación y re-creación del mundo. Pachacámac vence y expulsa a sus hermanos, pero sobre todo a Kon y vuelve a crear el mundo, lo trastoca. Es padre de Inti (dios del Sol) y de Mama Quilla (o la Luna).

En este territorio se edifica el templo de Pachacámac y el oráculo del Río Hablador ${ }^{35}$. Este oráculo es tan importante como lo fue el de Delfos en la Hélade y en el mundo helénico. El templo de Pachacamac, y su mar cercano, era $-\mathrm{y}$ es- centro de peregrinaje desde lugares muy remotos, con una gran leyenda que acompaña su culto y que tiene que ver con las dos islas que están frente al sitio arqueológico de Pachacamac en el valle de Lurín. Este culto y ese oráculo fueron tan importantes que, al llegar los incas a esta zona, no sometieron a los habitantes y al territorio, sino que capitularon

32 Aunque hay históricos de $8.8^{\circ} \mathrm{C}$ y de $33^{\circ} \mathrm{C}$, son temperaturas absolutamente anormales.

33 Pacha: tierra, mundo y tiempo y camac: soberano, gobernante.

34 Con el término andino nos referimos, siempre, a todo el territorio peruano y hasta sudamericano en el que la Cordillera de los Andes tiene influencia.

35 Rimay es hablar. 
con ellos y sometieron parte de su panteón al nuevo culto, adoptando, incluso, la lengua que se hablaba.

En el lugar que hoy ocupa la Plaza Mayor (mal llamada plaza de Armas), había un conjunto urbano muy importante en el momento de la llegada de los conquistadores. Ya era un territorio manejado por la élite local y representantes del Imperio Inca. En la plaza se encontraban dos edificaciones que representaban a ese Estado teocráticomilitar. En el emplazamiento del actual Palacio de Gobierno, al norte, estaba la huaca ${ }^{36}$ palacio de Tauli Chusco, el gobernante local $y$, en el lugar de la actual catedral, al este, se encontraba la Huaca-templo de Sinchi Puma, representante religioso y posiblemente tucuyricuy del Inca. Las versiones varían, pero al parecer había una tercera huaca, al oeste, que llamaban "del Cabildo". Estos tres elementos, edificados formando una U, con la abertura orientada al sur (hacia el santuario de Pachacamac). Por esta plaza se cruzaban dos ramales del Qapac Nan.

Los incas, para llegar a Pachacámac y Rimac Tampu (actual Lima) conquistaron con facilidad a Chuquismancu, señor de Runahuanac (Lunahuaná), Malla y Chilca. Con todo ello, hubiera podido conquistar, muy fácilmente, a Cuismancu, señor de los valles de Lurín (Pachacamac), Rímac (Maranga), Chancay y Huamán, pero prefirieron parlamentar. Debido al gran ídolo de Pachacamac y al oráculo de Rimac. Los incas reconocen el alto valor espiritual del pueblo de esta región y se proponen no realizar ninguna campaña sin antes consultar al oráculo del Rímac. Todo el valle estaba bañado por ríos-ramales artificiales que, derivando del Rímac, corrían hacia el sur-suroeste. El Huaycoloro, el Sulco, el Huatca y el Malanka son los más conocidos. Algunos de ellos están aún en funciones. Había un ramal que partía de detrás del actual palacio de gobierno y que era controlado por Tauli Chusco, con lo que, posiblemente el "gobierno" de este personaje tan solo haya sido el de controlador de la compuerta. Lo que Pizarro, sagaz en el manejo del poder, detectó como una gran ventaja. A este ramal se le llamó Magdalena. No estamos seguros de que se trate del mismo Malanka o de otro diferente

Lima fue la segunda capital fundada por Pizarro. La primera fue Jauja, en 1533, pero se descartó por ser muy frío, de muchas nieves, poca leña y pobres condiciones frente a una insurgencia de los indios. Pero Jauja luego ha sido conocida como de un clima ideal, sobre todo para los enfermos del pulmón. La idea que manejamos y por la que pensamos no se haya considerado nunca a Cusco, la capital del Imperio, como capital de la naciente colonia, y por la que se desechara Jauja, es la altura y la poca capacidad de reacción que podrían tener los españoles frente a los indios. La falta de puerto no es argumento, si consideramos que la capital de España, fue siempre mediterránea: Toledo, Valladolid y Madrid.

Así, al fundar Pizarro Lima, con el nombre de Ciudad de los Reyes, el 18 de enero de 1535, lo hizo trazándola a cordel. No encontró pre existencias arquitectónicas ni urbanas como en Cusco, así que más que Puma Cancha (la actual Plaza Mayor) y las huacas que la rodeaban, no había nada de consideración, por lo que la plaza no quedó en el "comedio de la población", como mandaban las "Ordenanzas" de Carlos V. Como sólitamente hacía Pizarro, superpuso edificio religioso sobre edificio religioso y edificio civil sobre edificio civil. Así, él, como gobernador, quedó al norte, sobre la huaca de Tauli Chusco, al lado del río, controlando las bocatomas, es decir, manejando el agua. La "huerta de Pizarro", que fue la de Tauli Chusco $^{37}$, se extendía desde la espalda de Palacio de Gobierno, hasta la actual plazuela Santa Clara. Había, pues, muchas bocatomas.

\footnotetext{
${ }^{36}$ Huaca significa sagrado. Un cerro, una piedra o una construcción pueden ser huaca, pero, en el castellano peruano actual, generalmente se le llama huaca, por extensión, a los edificios costeños construidos en barro y que están en condiciones de vestigios, muchos de ellos enterrados ex profeso, y que toman la forma de un cerro de tierra.

37 Durante siglos, Palacio de Gobierno estuvo sobre elevado (como sobre elevada está la Catedral), por la existencia de las huacas bajo ellas, lo que se ha comprobado por las excavaciones realizadas en el $2^{\circ}$ período presidencial del Dr. Alan García.
} 
La ciudad se trazó a cordel y a escuadra, sobre un plano previo, asignándose los solares, según la importancia y los privilegios de los nuevos vecinos. Los naturales no podían habitar cerca a la plaza, lo que no fue una novedad, pues como hemos visto, en los alrededores de la plaza no había pobladores. Estos, que sumaban cerca de 8000 habitantes en unas 1700 casas (bohíos), estaban en los arrabales y en los barrios satélites, como el pueblo de indios camaroneros, que estaban frente a palacio cruzando el río. Debemos considerar que el río, en la época de la fundación y algunas décadas más, estaba mucho más alto de lo que actualmente se encuentra, pues la velocidad de las aguas erosiona la madre y lo profundiza respecto a la ciudad.

En la plaza, Pizarro coloca el rollo y la picota, símbolo de la justicia civil. La catedral era el símbolo del poder religioso. Aunque en los planos hubo un olvido, el cabildo y la cárcel, estos se ubicaron sobre la tercera huaca, al oeste de la plaza. Pese a la excentricidad, por la importancia y peso político religioso de los edificios y las personas que se ubicaban en su perímetro y áreas aledañas, la plaza es el centro, tal vez no geométrico, pero sí simbólico de la ciudad de Lima, cuya forma y tamaño no variaron en casi 350 años. Fue, además el centro de gravitación, de la colonia, primero y del virreinato, después. Aún, luego del derribo de las murallas y del crecimiento de Lima hacia el sur, Lima cercado siguió llamándose "el Centro" y la Plaza Mayor era el centro del centro.

La plaza fue el núcleo generador de una ciudad cuyo trazo no era pre existente, como fue en Cusco. Se debió planificar, no solo la "lotización" y manzaneo, sino, la forma en que se abastecería de agua a la población y cómo llegaría al poblado. Obviamente no se pensaba en abastecimiento domiciliario, sino que, en atrios de iglesias, plazuelas y plazas de la ciudad habría pilones. Para ello aprovecharon una toma de agua que generaba acequias en la zona de Puma Cancha, llamada Cacca Wasi (la doble c se pronuncia como una J muy gutural) con lo que quedó como Caja de Agua y que bautizaron con el nombre de Atarjea ${ }^{38}$.

Muerto Pizarro, tanto el solar destinado a Casa del Gobernador (que daba frente a la plaza) y sus propios solares (detrás del palacio del Gobernador) formaron parte del Palacio de los Virreyes. Los solares destinados a García de Salcedo uno frente a la plaza y el otro en la esquina de los actuales jirones Junín y Lampa, por donación de este, pasaron a la iglesia. Así se pudo construir la catedral y el palacio arzobispal. Los solares de de Hernando Pizarro, uno que daba a la plaza y el otro, detrás, en la esquina de los actuales jirones Conde de Superunda y Camaná pasaron a ser la cárcel y el cabildo. Recordemos que en el planteo de trazado y en el reparto de solares, hubo un claro olvido del Cabildo, pese a que los primeros alcaldes, Nicolás de Rivera el Viejo y Juan Tello intervinieron en la planificación.

La Plaza Mayor de Lima, desde el inicio, sirvió para actos sociales de trascendencia social. En el atrio de la catedral, elevado por estar encima de una huaca, se escenificaban autos sacramentales, muy común en esas épocas, pues era una forma de educar en la fe. En la plaza se practicaban las ejecuciones, ya sean civiles o penales o religiosas, por autos de fe de la inquisición. Servía para corridas de toros y juegos de caña. Funcionaba el mercado. Las procesiones y otras fiestas religiosas se realizaban dentro en su perímetro o se iniciaban dentro de él. En caso de terremotos, servían de refugio de los pobladores. Si se recibía la noticia del nacimiento de algún infante o infanta, de la proclamación de un nuevo rey, de un triunfo militar, de la llegada de un nuevo virrey o de un nuevo arzobispo, en la plaza se construía alguna forma de arquitectura efímera especial para ese acto. De la plaza partían las expediciones militares o de conquista. Es decir, que mientras no se produjese un determinado acto en la plaza era como si no fuese oficial. La primera lectura de un bando se realizaba en la Plaza Mayor; servía de punto de reunión social, como fueron, posteriormente, los mercados.

38 En mayo de 1535 el cabildo resolvió "que es necesario para el servicio de la ciudad, que anduviese el agua por sus calles y solares, por sus acequias como solía antes que la ciudad se fundase..." 
Durante los primeros años de la conquista, las construcciones fueron de escasa calidad. Había que atender las sublevaciones de Manco Inca y la guerra civil entre pizarristas y almagristas. Recién, desde el virreinato del Conde de Nieva se iniciaron construcciones de calidad y el plantado de árboles en las huertas de las casas. Con ese virrey se construyeron los portales de la plaza, para que los viandantes queden libres de sol o la llovizna; mandó construir la pileta de piedra de la Plaza Mayor y cinco pilones (uno en cada esquina y otro en el atrio de la catedral), la misma que no llegó a inaugurar y lo hizo Francisco de Toledo en 1572. Esclavos, naturales sirvientes y aguateros se acercaban a la pileta para recoger un agua muy pura. Para que la pileta pudiera estar en medio, fue necesario trasladar rollo y picota al Callejón de Petateros (hoy pasaje Olaya).

Debido a problemas de la fuerte presión del agua, se cambió, ya en el siglo XVII, durante el virreinato del Conde de Salvatierra, por una pileta de bronce, que es la que se ve actualmente. La iconología de esta fuente es difícil de desentrañar, pues los ocho chorros que circundan a la pileta misma de tres tazones son leones y dragones o grifos que están en cópula. Es obra de Antonio de Rivas y se inauguró en 1651. Los lados semicirculares que conforman el plato de la fuente, coinciden con los puntos cardinales.

La plaza era una de las mejores del reino de España, pero su piso era de tierra, no tenía ninguna forma de mobiliario urbano. Entiéndase por esto bancas, faroles, etc. Todo esto llegó con el s. XIX. Sí tenía unos tendejones precarios en la parte baja del Palacio de los Virreyes y se llamaron (por el nombre de la calle) "cajones de la Ribera", que deslucían la plaza y el mismo palacio.

A fines del s. XVIII, en la esquina de las calles Bodegones (Jr. Carabaya) con Judíos (Jr. Huallaga), se abrió el primer café de Lima, lo llamaban "El Mentidero" y en él se tramaron y urdieron los primeros planes independentistas de los ilustrados.

De todas las esquinas la de Pescadería (Jr. Carabaya) con Arzobispo (Jr. Junín), el solar que le correspondió a Alonso de Riquelme tiene el edificio más antiguo, la llamada Casa del Oidor, que es una edificación que, en su parte inferior, data del s. XVI, y tiene un balcón sencillo. Fue de las 25 edificaciones que sobrevivieron al terremoto del 28 de octubre de 1746. Su última restauración, bastante respetuosa, fue en 1971.

En la segunda mitad del s. XIX, la plaza se transformó. Se le colocó piso de adoquines de piedras que conformaban figuras geométricas, con esculturas y árboles (Ficus nitida) cercadas por rejas bajas, se colocaron faroles, de kerosene, primero y de gas, después y bancas de mármol sin respaldar. Se eliminan las insalubres acequias y se reemplazan por desagües. Con Piérola se desalojaron los tendejones de la Ribera, se retiran los árboles y se llena la plaza de palmeras (Roystonea regia).

La ciudad crece y el automóvil hace su aparición. El alcalde Federico Elguera remodela la plaza modificando sus niveles, generando las vías perimétricas asfaltadas, se reemplazan las bancas de mármol por otras de piedra y se inició la apertura de lo que sería la Av. Santa Rosa y que, no se llegó a terminar excepto el tramo de la plaza al Jr. Camaná (1 cuadra), cicatriz que le ha quedado. En esta época se abre la tienda Oechsle de varios niveles con ascensor y formas gotizantes, lo que hace desaparecer la portada del Callejón de Petateros. A partir de estas aperturas se modificó el espacio de la plaza, no porque cambiase la forma geométrica de la misma, sino porque generó dos ejes de tensión que "traccionan" la vista de forma inusual en una plaza mayor que, como se ha dicho ha de ser cerrada, distrayendo la vista de la centralidad que debe tener.

En 3 de julio de 1920 se incendió el Palacio de Gobierno. Al parecer, enemigos políticos de Leguía querían que las celebraciones por el centenario de la independencia fracasen, lo que no ocurrió pues en rápida reacción, el presidente mandó edificar lo que se conoció como el Palacio de Cartón. El año 26 Claudio Sahut inicia la construcción del nuevo Palacio de Gobierno, obra que concluirá Ricardo de Jaxa Malachowski durante el gobierno dictatorial del general Oscar Benavides. 
A inicios del s. XX se decidió edificar un nuevo Palacio Arzobispal y el proyecto le es encargado al Arq. R. J. Malachowski quien lo diseñó en estilo neocolonial barroco afrancesado con unos maravillosos balcones tallados.

En noviembre de 1923 se incendia la Municipalidad y no se rehace hasta la década de los 40 por el arquitecto. Emilio Harth-Terré, quien conjuntamente con el arquitecto Álvarez Calderón diseña los portales y las arquerías nuevas de la plaza luego del terremoto del 24 de mayo de 1940. El diseño incluyó reponer sendas portadas, una en el Callejón de Petateros y colocar otra, mayor, de un arco, en el pasaje. Santa Rosa. Esto para mantener el espacio propio de una plaza mayor. Luego se retiran las bancas de piedra y se colocan otras de madera con respaldar, se recorta el área central de la Plaza para dar lugar a estacionamientos periféricos y se siembran cedros en los jardines. Además, se abre la plazuela Pizarro, para ubicar en ella el monumento al conquistador.

Como se dijo, la plaza ha sido testigo de los innumerables terremotos que azotaron Lima y fue refugio de los damnificados, sobre todo luego de los de 1606, 1687 y 1746. Siendo, hasta este último, más de 15 los que están registrados como destructores. Por esta razón, Jorge Bernales Ballesteros dice que se llamó plaza de la alarma, de donde, posiblemente, venga el errado nombre de plaza de armas. Lo que no puede seguirlo siendo por los jardines y el paso de vehículos.

En años recientes, el espacio central de la plaza ha recuperado un poco su tamaño, pero la presencia de las áreas verdes no la definen como tal con claridad. A eso sumemos el retiro de la estatua ecuestre de la Plaza Pizarro que, aunque de una manera precaria contenía el espacio, y es reemplazada por una pileta. Las aberturas del pasaje Olaya y del pasaje Santa Rosa y el "patio de honor" de palacio de gobierno contribuyen a la indefinición espacial de lo que debería ser un espacio cerrado de Plaza Mayor iberoamericana, como la de México D.F. (el Zócalo) que recuperó su área útil, luego de retirar el ajardinamiento de mediados del s. XX.

La plaza es más lugar de paso que de contemplación.

Si bien con la independencia la plaza elevó su importancia y simbolismo, pues el centro el gobierno ya no estaba en Valladolid o Madrid, sino en Lima, este simbolismo decreció con la declinación de la república oligárquica.

La plaza sigue siendo, simbólicamente, el centro de Lima y del Perú pero porque en ella están los máximos poderes de decisión nacional, provincial y religioso. Porque, aún con todo por lo que ha pasado, es la plaza más importante de la capital, pero ya no marca jerarquía la proximidad o lejanía a ella que se tenga, con lo que el simbolismo para la misma ciudad de Lima. Ya no se realizan los desfiles ni las corridas de toros. Ya no es el mercado. $\mathrm{Ni}$ se hacen los mítines políticos. Muchas de sus funciones han sido desplazadas en 1921 a la plaza San Martín, al Campo de Marte o a la Av. Brasil. Pero la entrada de la Procesión del Señor de los Milagros, para recibir los honores del presidente de la República, del alcalde de Lima y del Arzobispo es el punto de inflexión máxima en su recorrido. Igualmente importante es el cruce del presidente al $\mathrm{Te}$ Deum de Fiestas Patrias.

La plaza congrega visitantes al momento del diario cambio de guardia, por el atractivo que tiene no solo para los turistas, sino para todos los que están en ese momento.

Ya no hay autos sacramentales en el atrio de la catedral, pero es común ver a recién casados fotografiándose en el atrio con el fondo de las torres el imafronte o el palacio arzobispal. Es el lugar de Lima que los turistas no dejan de ver.

La plaza Mayor de Lima es igualmente usada por los turistas como por los habitantes de Lima, sean estos vecinos de ella o de distritos alejados. Es un punto a favor que tiene, respecto a la de Cusco que es más usada turísticamente. 


\section{CONCLUSIONES}

- Las plazas mayores latinoamericanas no vinieron de España, sino que fueron una forma de mestizaje urbano entre las plazas de los centros urbanos pre hispánicos (Aztecas, Mayas, pre incas e Incas) y las plazas religiosas y del cabildo europeas. Luego se trasladaron a la península.

- Las plazas sirven, como dice, Lynch, a la imaginabilidad de la ciudad, es decir, a su reconocimiento e identidad como tal, dándoles legibilidad y por eso son lugares preferidos por los visitantes.

- Debe reeducarse a la población en lo que significa el espacio plaza, frente a los parques. La escasez de plazas, frente a los parques hará que se desbanalicen.

- $\quad$ En general, a las plazas mayores del Perú: Cusco, Lima, Ayacucho, Moquegua, Chiclayo, Trujillo, etc. deberían retirárseles el aire a parque que tienen. Las islas jardín deberían reducirse para un mejor uso general de la plaza y el área central debería crecer hasta los portales, restringiéndose el tráfico automotor a vehículos oficiales y de emergencia. Se ha instalado en el imaginario popular la idea de parque más que de plaza. Esto le hace perder prestancia a las plazas.

- Las plazas deben recuperar su sentido de lugar de estar y de encuentro ciudadano, de tranquilidad. Ya no serán el medio de comunicación social, como en el pasado, pero deben mantener su esencia humana de actividades urbanas.

- La Plaza Mayor de Cusco necesita retomar un espíritu más ciudadano y menos cosmopolita o turístico. La ciudad es, ante todo, para sus habitantes y la plaza es el corazón de la ciudad.
- La Plaza Mayor de Cusco debe reducir sus áreas de jardín y cambiar los individuos vegetales que se encuentran en mal estado.

- La Plaza Mayor de Cusco mantiene una unidad de estilos en las edificaciones aunque el tiempo y los terremotos hayan marcado cambios.

- Estéticamente, la Plaza Mayor de Lima necesita -y su jerarquía lo exige- algunos cambios, tanto en la superficie como en el manejo del espacio urbano paisajista simbólico, así como en las especies vegetales que la acompañen. Las tropicales palmeras (Roystonea regia, que son el árbol nacional de Cuba) deberían retirarse. Lima no es tropical ${ }^{39}$.

- La Plaza Mayor de Lima, para evitar las tensiones generadas por los pasajes abiertos, necesita recuperar su carácter cerrado con pórticos de acceso al Pasaje Santa Rosa y al Pasaje Olaya, como lo preveía el proyecto de Harth-Terré y Álvarez Calderón, bien sea siguiendo sus planos o de otra forma. Igualmente, lograr, manteniendo la Plazuela de la Peruanidad (antes Pizarro), un cerramiento virtual del espacio.

- En la plaza de Lima se debe mejorar la calidad de los comercios que se encuentran en el Portal de Botoneros (lado sur) para devolver el nivel de servicios que se merece.

- La Plaza Mayor de Lima mantiene una paradójica unidad en la variedad de estilos que existen en ella, sobre todo por la calidad de sus edificaciones, a excepción de las esquinas de Judíos y Mantas.

\footnotetext{
39 No nos oponemos al uso de estas palmeras en Lima pues son muy hermosas, sino que consideramos que, dada la trascendencia del simbolismo de la Plaza Mayor, no debería estar en ella por no ser representativas.
} 


\section{REFERENCIAS}

Agurto, S. (1979) Cusco, la traza urbana de la ciudad Inca. Lima: UNESCO/INC.

Araujo, I. (1974) La forma arquitectónica. Navarra: EUNSA.

Azevedo, P.y Ormindo, D. (1982) Cusco Ciudad Histórica. Continuidad y cambio. Lima: UNESCO.

Bernales, J. (1972) Lima La ciudad y sus monumentos. Sevilla: Escuela de Estudios HispanoAmericanos.

Betanzos, Juan de. 1987 (1551): Suma y narración de los Incas que los Indios llamaron Cápac Cuna. Madrid: Atlas.

Brandi, C. (1988) Teoría de la restauración. Madrid: Alianza Editorial.

Ching, F. (1982) Arquitectura forma, espacio y orden. Barcelona: Gustavo Gili.

Chueca Goitia, F. (1991) Breve Historia del urbanismo. Madrid: Alianza.

Cuadros, M. (1946) Historia y Arquitectura de los templos del Cuzco. S.N.E.

Cullen, G. (1974) El Paisaje Urbano. Barcelona: Ed. Blume.

De Orellana Rojas, J. (1983) La Plaza Mayor de Lima. Monografía presentada para el curso Arquitectura Paisajista. U. de Lima (mecanografiado).

De Orellana Rojas, J. (1992) Arquitectura e Identidad. Lima: UNIFE (mimeografiado).

De Orellana Rojas, J. (2001) Estudio comparado de las imágenes urbanas de las ciudades medievales y la de Cusco ( $1^{\text {a }}$ parte). Lima : En CONSENSUS, Revista de la Universidad Femenina del Sagrado Corazón, Año 6 Nº 6.

De Orellana Rojas, J. (2003) Estudio comparado de las imágenes urbanas de las ciudades medievales y la de Cusco (2a parte). Lima: En CONSENSUS, Revista de la Universidad Femenina del Sagrado Corazón, Año 7 N 7 - 8.

Hardoy, J., et alt. (1983) El Centro Histórico del Cusco. Lima: UNESCO.

Krier, R. (1981) El espacio urbano. Barcelona: Gustavo Gili.

Lynch, K. (1974) La Imagen de la Ciudad. Buenos Aires: Infinito.

Makowsky, K. (1996) La ciudad y el origen de la civilización en los andes. Lima: Pontificia Universidad Católica.

Municipalidad del Qosqo (1993) Diagnóstico del Hawkaypata. Plaza Mayor de la capital histórica del Perú. Cusco: Municipalidad del Qosqo.

Norberg-Schultz, C. (1975) Existencia, Espacio y Arquitectura. Barcelona: Ed. Blume. 
Norberg-Schultz, C. (1983) Arquitectura Occidental. Barcelona: Gustavo Gili.

Ortega y Gasset, José (1950) El Espectador I - VIII. Madrid: Biblioteca nueva.

Peralta, R. y Samanez, R. (1993) La Idea de Plaza. Cusco: Municipalidad del Qosqo.

Quezada, Ó. (2007) Del mito a la forma simbólica. Ensayo de hermenéutica semiótica. Lima: Fondo editorial Universidad de Lima, Fondo Editorial UNMSM.

Rostworowski, M. (1988) Historia del Tawantinsuyu. Lima: I. E. P.

Rostworowski, M. (1997) Pachacútec y la leyenda de los Chancas. Lima: Instituto de Estudios Peruanos.

Scruton, R. (1985) La estética en arquitectura. Madrid: Alianza Editorial. Alianza Forma.

Spreiregen, P. (1971) Compendio de arquitectura urbana. Barcelona: Editorial Gustavo Pili.

Williams León, C. (1991) Pachacútec y la Arquitectura. (Mecanografiado. 19 pag). 